\title{
The Role of Omega 3 Fatty Acids in Memory Improvement: Possible Mechanisms and Therapeutic Potential
}

\author{
Amare Abera Tareke* Wondu Reta Demissie Moyeta Barisso Gare \\ Department of Biomedical Sciences, Institute of Health, Jimma university, Jimma, Ethiopia
}

\begin{abstract}
Omega-3 polyunsaturated fatty acids ( $\omega-3$ PUFAs) from fish and plant sources are promising dietary supplements to improve brain functions and slow down the progression of memory loss. Previous findings of preclinical, clinical and epidemiological research indicated there is a potential for consideration in therapeutic agent. We summarized the most relevant works literature in understanding the mechanism of omega 3 fatty acids induced memory improvement. The first part of this review focuses on discussion of omega 3 fatty acids and mechanism of memory, emphasis is given to the role of omega 3 PUFAs on memory at different stages/sites of memory formation: including effect on neuronal membrane, neurotransmitter exocytosis, concentration of neurotransmitters, receptors, and signaling molecules as well as neural plasticity for long term memory. The therapeutic potential of omega 3 PUFA in neurocognitive disorders is also summarized from recent clinical trials. Keywords: Omega 3 fatty acids, memory, neurotransmitters, signaling molecules, therapeutic potential
\end{abstract}

DOI: $10.7176 / \mathrm{JMPB} / 54-01$

Publication date: April $30^{\text {th }} 2019$

\section{Introduction: Omega 3 fatty acids}

Fatty acids containing a double bond are unsaturated fatty acids, ( $\omega-3)$ or Omega 3 fatty acid is a family of PUFA, where the number representing the position of the double bond, the occurrence of multiple double bonds in FA also considered by addition of the word "poly"[1]. The synthesis of fatty acids from linoleic acid requires desaturase enzymes because some of these desaturase enzymes are absent in animals including human beings, they are unable to form $\omega-3$ or $\omega-6$ fatty acids de novo and must obtain from their diet. But they can metabolize $\alpha$-linolenic acid to other longer chains, more unsaturated ( $\omega-3)$ fatty acids, including Eicosapentaenoic acid (EPA), Docosahexaenoic acid (DHA), and Arachidonic acid (AA) [2,3].

$\alpha$-Linolenic acid conversion to EPA, DPA, and DHA is reduced in humans, in particular, conversion to the end product DHA appears to be especially is inadequate, summerized in Figure 1 [4]. EPA, DPA, and DHA are often collectively mentioned as very long-chain $(\omega-3)$ PUFA.

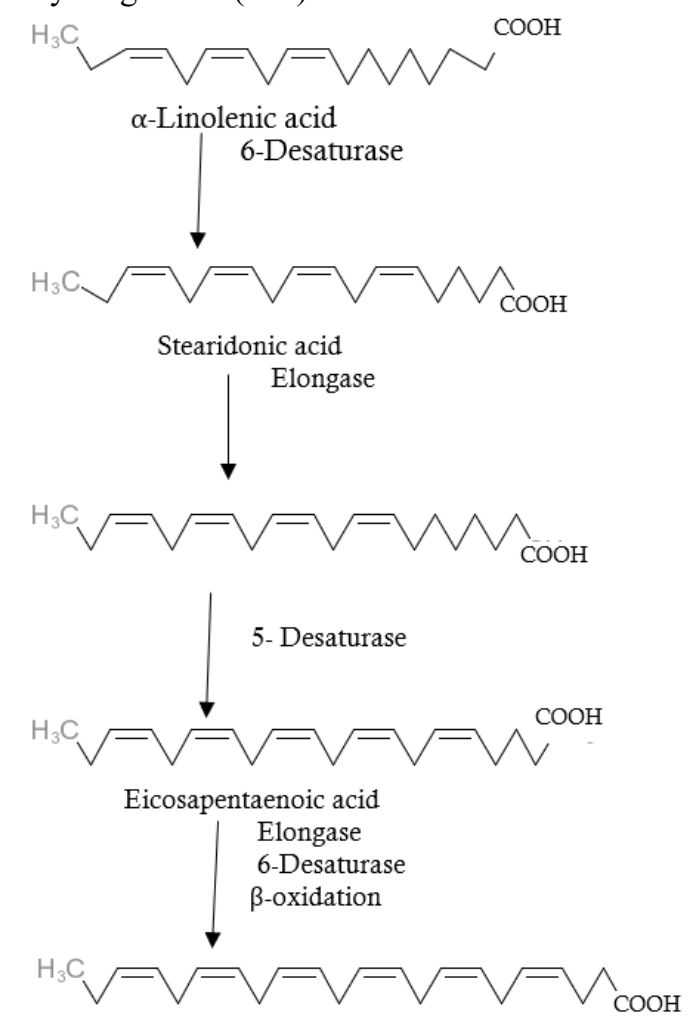

Decosahexaenoic acid 
Figure 1. Pathways of $\alpha$-Linolenic acid conversion to longer chain, more unsaturated omega-3 fatty acids

EPA and DHA, are Omega-3 long-chain PUFA dietary fats with a range of health benefits [6], principally integrated into the membranes confer important properties to cell membranes [7], providing DHA for brain tissue growth and function [8]. Play a role in anti-inflammatory processes and alter the fluidity of cell membranes $[9,10]$. EPA and DHA are the indispensable component of proper development and healthy aging [11]. Several lipid mediators are produced from EPA and DHA metabolites [12], these lipid mediators together with the parent compound revealed by many authors as advantageous in the prevention or management of numerous diseases.

In this review we will focus on the role of omega 3 fatty acids on memory: emphasis will be given to effect omega 3 fatty acids on neurotransmitters and signaling molecules in memory pathways.

\section{Introduction: Mechanism of memory}

Memory refers to the storage of learned information in the brain, and is crucial for adaptive behavior in animals, and is associated with gene expression, protein synthesis, and the growth of new synaptic connections at least in long term [13]. Several neurotransmitters are involved in memory, including cholinergic, serotonergic, dopaminergic, GABAergic and noradrenergic neurotransmitters [14]

\subsection{Short term and intermediate memory}

The stimulus in short term memory formation leads to the activation of modulatory neurons that release neurotransmitter (serotonin) onto the sensory neuron [15]. The serotonin will act on the receptors, increases the concentration of cyclic adenosine monophosphate (cAMP) in the sensory cell [16]. cAMP increment is crucial, it is witnessed [17] injecting cAMP directly into the sensory neuron produces temporary strengthening of the sensory-motor connection.

In presynaptic terminals cAMP recruits the cAMP-dependent protein kinase A (PKA) by binding to the regulatory subunits, causing them to dissociate from and free the catalytic subunits [18]. These subunits can then phosphorylate channels and exocytosis machinery in the presynaptic terminals, causing greater neurotransmitter release and availability [19]. This, in turn, causes momentary increase excitability and widening of the action potential by decreasing specific $\mathrm{K}^{+}$currents, to allow greater $\mathrm{Ca}^{2+}$ influx into the presynaptic terminal with each action potential [20]. The greater $\mathrm{Ca}^{2+}$ influx contributes to the enhanced transmitter release like glutamate. Glutamate released into the synaptic cleft, temporarily strengthening the connection between the sensory and motor neuron.

Today the best possible explanation for calcium-dependent presynaptic neurotransmitter release is through synaptotagmin, an integral protein of synaptic vesicles [21]. Cytoplasmic domains of some identified synaptotagmins have two repeating structures, called $\mathrm{C} 2$ domains. Calcium binds with the $\mathrm{C} 2 \mathrm{~A}$ and $\mathrm{C} 2 \mathrm{~B}$ domains of synaptotagmin, $\mathrm{Ca}^{2+}$ binding to acidic residue on the $\mathrm{C} 2$ domains of synaptotagmin enhances the association between synaptotagmin and the plasma membrane Soluble NSF Attachment Protein Receptor (SNARE), syntaxin [22,23].

The effects of serotonin on memory depend on the activation of serotonergic receptors located on distinct subsets of neurons [24]. Many of these effects are produced through the modification of cholinergic, dopaminergic, GABAergic or glutamatergic transmission [25]. Facilitation during intermediate-term sensitization involves both presynaptic (PKA, $\mathrm{Ca}^{2+} /$ calmodulin-dependent protein kinase II (CaMKII)) and postsynaptic $\left(\mathrm{Ca}^{+}\right.$, CaMKII) covalent modifications, as well as both presynaptic and postsynaptic protein synthesis [26]. Short-term and intermediate-term memory correspondences synaptic strengthening that lasts from minutes to hours, and long-term memory parallels synaptic strengthening that persists from days to weeks [27].

\subsection{Long term memory}

Protein synthesis and gene expression are required for long-term memory formation [28], after repeated release and long-term sensitization by serotonin [29]. To demonstrate the pathway for long term memory formation various previous works of literatures revised [30-34], repeated and long term sensitization by serotonin increases the release of glutamate, then bind to AMPA receptors postsynaptically and depolarizes the membrane allowing $\mathrm{Ca}^{2+}$ entry accompanied by stimulation of N-methyl-D-aspartate (NMDA) type glutamate receptors [35]. Adenylyl cyclase activation by $\mathrm{Ca}^{2+}$ or by modulatory inputs through $\mathrm{G}$-protein-coupled receptors results in long term potentiation (LTP). A cascade of molecules including PKA activated in response to increase in cAMP level then translocates into the nucleus and phosphorylates cAMP response element binding protein (CREB). In addition, the persistent increase in cAMP recruits mitogen-activated protein kinase (MAPK) [36,37]; through catalytic subunit of cAMP-dependent protein kinase (PKA).

CREB and MAPK then move to the nucleus phosphorylates transcription factors and activates the gene expression required for long-term memory, PKA activates gene expression by means of the cAMP response element binding protein of CREB-1 [38]. CREB-1 induces the transcription factor CCAAT-enhancer binding 
protein $(\mathrm{C} / \mathrm{EBP})$, which is critical for long-term facilitation and leads to the second wave of gene expression that produces the growth of new synaptic connections [39], brain-derived neurotrophic factor (BDNF) and tissue plasminogen activator (tPA) are among the effectors activated [33].

Several kinases and phosphatases modulate CREB mediated responses including PKA, CaMKII, CaMKIV, RSK2, MAPK, and PKC, suggesting involvement and extensive cross talk of different pathways [40]. Ling Du and Joel D. Richter conducted a functional assay to identify Activity-dependent polyadenylation of brain-derived mRNAs in neurons injected into surrogate Xenopus oocytes and found many mRNAs undergo activitydependent polyadenylation in neurons corresponding with increased translation in the synapto-dendritic compartment [41]. Among them gamma CaMKII, ABP, ELK2, Map2, RCM3, alpha CaMKII showed activitydependent phosphorylation, all the proteins encoded by them (ABP, dCaMKII, aCaMKII, RCM3/calmodulin, Map2) are found in dendrites, the proteins encoded by two of the mRNAs, Map2 and ABP, are synthesized in synaptoneurosomes treated with glutamate [41].

Activation of CREB-1 and inhibition of CREB-2 accelerate long term memory formation, both excitatory and inhibitory transmitters can activate signaling pathways that activate/inhibit transcription via CREB-1 and CREB-2 and subsequently affect the structure of nucleosomes through acetylation and deacetylation of the residues of histone proteins in chromatin [42]. Agents that decrease the activity of CREB-1 specifically block the formation of long-term memory, whereas agents that increase the amount or activity of the transcription factor accelerate the process [43].

\section{Omega 3 fatty acids and memory}

Recent researches are examining the neurocognitve aspects of omega-3 fatty acids (alpha-linolenic, eicosapentaenoic, docosahexaenoic) and the critical role of these essential fats in the functioning of the central nervous system. Investigations have linked omega-3 fatty acids to a number of neurocognitive disorders, omega 3 fatty acids generally investigated for their effect on memory [44-47].

\subsection{Omega 3 fatty acids and neurotransmitter exocytosis}

Action potential arriving at a nerve terminal allows $\mathrm{Ca}^{2+}$ entry through voltage-dependent $\mathrm{Ca}^{2+}$ channels [48]. Calcium ions then bind to synaptotagmins [49]. The release of neurotransmitter involves the recruitment of the SNARE protein complex which provides the driving force to initiate the fusion of secretory vesicles with the plasma membrane [50]. Accordingly, the presence of several important proteins, such as SNARE proteins (SNAP25, Syntaxin, and VAMP2), Munc18, Synaptophysin and synaptotagmins [51-53], has been observed during exocytosis. It was proposed that segregation of these proteins into different membrane may have a regulatory role on neurotransmitter release [54].

Synaptophysin, which reflects synaptic density and synaptic vesicle formation, shown to increase expression in omega 3 PUFAs supplementation [55]. In another study, although, genes encoding for synaptotagmin1, syntaxin1A and synaptobrevin1 not affected by PUFA incorporation in the membrane, increases exocytosis and neurotransmission was observed [56].

\subsection{Omega 3 fatty acids and neurotransmitters}

\subsubsection{Serotonin}

Serotonin synthesized from its precursor amino acid tryptophan, released from the presynaptic neuron and act on its receptors. The amino-acid l-tryptophan reduction can cause weakening of serotonin activity [57], but researches are deficient on the role of omega 3 fatty acids and tryptophan concentration. Diet-induced perinatal omega-3 fatty acid depletion is associated with significant alterations in 5-HT and 5-HIAA content in the bain of rats [58]. Arachidonic acid an omega 6 fatty acid can generate prostaglandin E2, which are potent inhibitors of serotonin discharge [59]. Generation of $\mathrm{E}_{2}$ series prostaglandins can be inhibited by EPA in both young and old individuals [60]. Because of this action EPA in the brain might be important for normal serotonin release, which is evidenced by the positive correlation between human plasma omega-3 levels and serotonin metabolite in cerebral spinal fluid [61].

Since serotonin has G-protein coupled receptor and membrane lipid composition affects the receptor activity [62], Omega-3 fatty acids can influence serotonin function through membrane composition. Membrane fluidity is well maintained by DHA [63]. As the membrane becomes more fluid to a certain extent the serotonin receptors become accessibility can bind with ease [64]. Supporting this idea, a decrease in omega-3 fatty acids were linked with diminished serotonergic neurotransmission [65], and DHA deficiency decreases the concentration of serotonin in the frontal cortex [66]. Diet rich with fish tends to restore normal serotonin activity by increasing serotonin transporter proteins [67]. Besides serotonin, fish oil supplementation stabilizes the endocannabinoid 2-arachidonylglycerol (2-AG), dopamine (DA), neuropeptide Y (NPY), and CaMKII, silent mating type information regulation 1 (SIRT-1), and BDNF [68]. 


\subsubsection{Glutamate}

Since its discovery the function of glutamate in synaptic transmission, plasticity and development are well wellknown; acting through three three receptor classes, NMDA receptor, the AMPA receptors (AMPARs) and Metabotropic glutamate receptors (mGluRs) involved in memory [69]. Omega 3 fatty acids deficiency decrease vesicular glutamate transporter 1 (VGlut-1) and vesicular glutamate transporter 2 (VGlut-2) with alteration in glutamate discharge amount in old rats [70]. Glutamate uptake in the synapse by astrocytes via glutamate transporters is well inhibited by DHA, which increase glutamate concentration at the synapsed by slow down removal regulates synaptic efficiency [71]. Age-induced deprivation of glutamatergic transmission in the hippocampus and memory deficit is aggravated by $\omega-3$ PUFA deficiency, making clear the possible importance in this manner [70].

In transgenic mouse model of Alzheimer's disease, dietary n-3 PUFA reduction was coupled with initiation caspases and reduction in NMDA receptors in the brain [72]. Dyall SC. and his colleagues [73], noted dietary supplementation of old animals with omega-3 PUFA reverts GluR2 and NR2B glutamate receptor deficits, and improve phospholipid fatty acid profiles, with relevant changes in glutamatergic transmission. Ontogenetic experiments in rats [74], and glutamic synapse, omega 3 PUFA deficiency delayed ontogenic development of NMDA, AMPA, CaMKII contents, although normalized later in adulthood, hippocampal phospholipid DHA content reduction was also associated with decreased brain function and neural plasticity.

\subsubsection{Acetylcholine}

Acetylcholine is also indicated as one of neurotansmitters in different stages of memory formation [75]. Acetylcholine in different brain areas could augment LTP and nicotinic enhancement of LTP [76]. In memory impairment induced by IL-1 $\beta$ adimistration, which is directly related to memory deficits by diminishing acetylcholine release, $\omega-3$ fatty acids considerably enhanced memory by overturning [77]. The ( $\omega-3$ ) PUFA insufficiency caused a significant loss of DHA in the membrane and accounted for $10 \%$ drop in muscarinic receptor binding [78]. Thus, diet lacking $\omega-3$ PUFA decreased cholinergic neurotransmission, perhaps by altering membrane composition.

\subsubsection{Other neurotransmitters}

$\omega-3$ PUFA deficiency during lactation can alter neural activity including dopaminergic transmission [79]. It has been postulated that DHA restores dopamine receptor density in disease conditions affecting dopamine receptors [80], also dopamine-containing vesicles decrement were associated with $\omega-3$ PUFA deficiency [81], accompanied by decreased neurotransmitter concentration, alteration in membrane characteristics and monoamine transporters.

\subsection{Omega 3 fatty acids and Neural plasticity}

In the formation of long term memory, which, accomplished by new protein synthesis and gene expression, synaptic plasticity will take place, either in the form of long-term potentiation (LTP) or long-term depression (LTD) in various brain areas with multiple signaling molecules [82]. LTP and LTD are a result of modifications in postsynaptic AMPAR phosphorylation [83]. LTP is linked with ser-831 of CaMKII and PKC [84,85], on the other hand, LTD was found to be associated with ser-845, devoid of any alteration in ser-831 [86].

Morphological changes in LTP consist of growth of new dendritic spines, enlargement of preexisting spines and their associated postsynaptic densities (PSDs), and the splitting of single PSDs and spines into two functional synapses $[87,88]$. On the other hand, Roberto Malinow and Robert C. Malenka in 2002 published a review on AMPA receptor trafficking and synaptic plasticity putting together shreds of evidence on activitydependent changes in synaptic function lie behind in memory formation, there was AMPA receptor endocytosis in LTD and transport of AMPA receptor to synapses during LTP [89].

NMDA receptors stimulate the generation of phospholipase $\mathrm{A}_{2}$, which is important in LTP, arachidonic acid act presynaptically to modify neurotransmitter release in LTP [90], deficiency of arachidonic acid decreases phospholipase $\mathrm{A}_{2}$ activity and diminishing in LTP [91]. Deficiency of arachidonic acid can be reversed by dietary supplementation of DHA, DHA not only stabilizes arachidonic acid, but also restores normal neurotransmitter release and the diminishing in LTP in old rats [92]. DHA is vital for the initiation of LTP [93] and blocks LTD in vitro [94]. Numerous writings estabilished dietary deficiency of $\omega-3$ PUFA accelerates the aging by declining longevity and learning ability in rats $[95,96]$.

In doing so, DHA could act on postsynaptic sites [97], inhibiting the $\mathrm{K}^{+}$channel [98]. Since the $\mathrm{K}^{+}$channel blockers, can induce NMDA-independent long lasting modulation in the Schaffer collateral of hippocampal slices [99], it is probable that DHA may act through this channel. Besides, other pieces of vidence also support this concept [100-102], $\mathrm{K}^{+}$channel regulates backpropagation of action potentials [103]. Because the backpropagation is identified to regulate synaptic plasticity[104], limiting back propagation [105,106], DHA may contribute to LTP by changing membrane excitability.

The diet containing DHA enhanced levels BDNF, CREB and synapsin I, Akt, and CaMKII, and reduced hippocampal oxidized protein levels [107]. Akt and CaMKII signaling are decisive in BDNF action on synaptic 
plasticity and memory [108]. Contrary to this study, $\omega-3$ deficiency disturbed BDNF and components of BDNF signaling pathway (TrkB, CaMKII, Akt and CREB) [109]. Putting together enrichment of diet with omega-3 FA could stabilize the levels BDNF, and thus, regulate neural plasticity [110].

\subsection{Omega 3 fatty acids and gene expression}

Kitajka $\mathrm{K}$ et al. conducted extensive measurement on changes of rat brain gene expression by dietary $\omega-3$ fatty acids, a number of genes over expressed and some under expressed [111]. The ATP-generating machinery of the brain increased to $\omega-3$ fatty acids intensively, maintaining ionic balance and maintaining Na-K ATPase activity is important in nerve transmission [112]. Amplification of proteins involved in signal transduction (calmodulins, etc.) and plasticity has been suggested [113]. Genes encoding synuclein $\alpha$ and gama also were overexpressed [111]. Synuclein $\alpha$ involved in neural plasticity and is related to learning in the brains of songbirds, its role in synaptogenesis has also been proposed [114], and it is discussed previously plasticity involves morphologic changes, synaptogenesis in the cerebellar cortex of adult rats was shown [115].

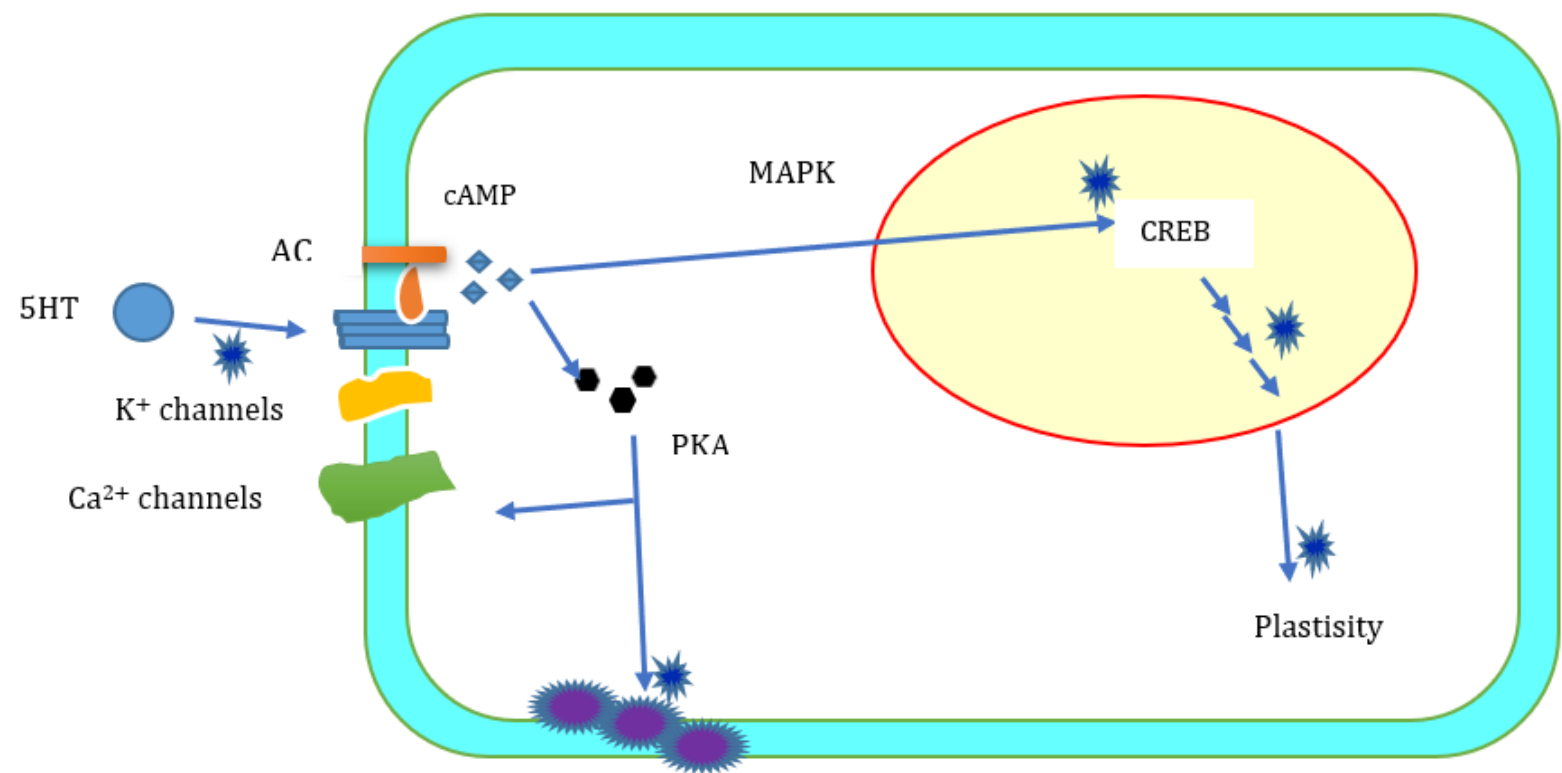

Figure 2. Possible effects of omega 3 PUFA in short term and long term memory: in short term sensitization a transient release of serotonin leads to modification of pre-existing proteins. The serotonin acts on a transmembrane serotonin receptor to activate the enzyme adenylyl cyclase (AC), which converts ATP the second messenger cyclic AMP. In turn cyclic AMP recruits cAMP-dependent protein kinase A(PKA), then phosphorylate substrates (channel and exocytosis machinery) in the presynaptic terminals, leading to enhanced transmitter availability and release. In long term sensitization, repeated stimulation causes the level of cAMP to rise and persist for several minutes. The catalytic subunits can then translocate to the nucleus, and recruit the mitogen activating protein kinase (MAPK). In the nucleus, PKA and MAPK phosphorylate and activate the cAMP response element-binding (CREB) protein activating several immediate-response genes, and leading to different forms of plasticity. Omega 3 PUFAs increase the availability of neurotransmitters, receptors, membrane fusion for exocytosis, signalling molecules indicated by the blue star.

\section{Evidence of omega 3 fatty acids as therapeutic agents}

Clinical trials mainly focused on the treatment of dementia, supplementation in healthy adults and developing children. In elderly omega 3 fatty acid supplementation for cognitive decline and dementia have promising advantages, omega-3 supplementation reduces verbal episodic memory deteriorations [116], n-3 PUFAs integrated into phosphatidylcholine, activate cognitive function in the elderly [117]. In elderly with memory complaint without dementia, DHA improves cognitive performance [118].

The beneficial effect of n-3 PUFAs in the elderly at risk of dementia is recognized [119]. Increased consumption of DHA and EPA helped mental conditions in older people by reducing the risk of progressing to dementia [120], long chain omega 3-FA enhance memory functions in healthy older adults [121]. On the other hand, 90 days of DHA supplementation showed no significant effects on cognitive functioning in healthy aging population [122], and Polyunsaturated fatty acids, on cognitive decline over 3 years in elderly people with memory complaints in another study [123].

Results from PUFA levels and cognitive performance measures in children also indicated omega 3 supplementation, and decrease the consumption of $\omega-6$ fatty acids are important for cognitive function [124,125]. 
Following the EPA-rich supplementation, of young adults, neurocognitive functioning was enhanced after a 30-day of supplementation in the same group of individuals than prior to supplementation [126].

The accumulated knowledge indicates that healthy populations may have preventive benefits from omega 3 PUFA intake, and older adults with memory complaints or mild cognitive impairment, and maybe subgroups of patients with mild/moderate Alzheimer's disease may also show such benefits [127]. Also, consumption of DHA at a dosage of $300 \mathrm{mg} /$ day for 15 weeks or $100 \mathrm{mg} /$ day for 30 weeks is recommended for non-demented elderly as safe, well tolerated, and without negative effects [128].

Table 1: recent trials of omega 3 PUFA supplimentation and cognitive function

\begin{tabular}{|c|c|c|c|c|c|c|c|c|}
\hline No & Study & Subjects & $\begin{array}{l}\text { Sample } \\
\text { size }\end{array}$ & Supplimentation & Duration & $\begin{array}{l}\text { Parameters } \\
\text { measured }\end{array}$ & Response & Citation \\
\hline 1 & $\begin{array}{l}\text { Jaremka et } \\
\text { al., } 2014\end{array}$ & $\begin{array}{l}\text { Healthy, } \\
\text { overweight } \\
\text { and } \\
\text { sedentary } \\
\text { adults }\end{array}$ & 138 & Omega 3 PUFA & 4 months & $\begin{array}{l}\text { Verbal episodic } \\
\text { memory }\end{array}$ & Attenuated & [116] \\
\hline 2 & $\begin{array}{l}\text { Konagai et } \\
\text { al., } 2013\end{array}$ & $\begin{array}{l}\text { Males aged } \\
61-72 \text { years }\end{array}$ & 45 & $\begin{array}{l}\text { Krill oil or sardine } \\
\text { oil (n-3 PUFA) }\end{array}$ & 12 weeks & $\begin{array}{l}\text { working } \\
\text { memory task, } \\
\text { changes in } \\
\text { oxyhemoglobin } \\
\text { concentrations }\end{array}$ & $\begin{array}{l}\text { Significantly } \\
\text { greater than } \\
\text { controls }\end{array}$ & [117] \\
\hline 3 & $\begin{array}{l}\text { Vakhapova } \\
\text { et al., } 2010\end{array}$ & $\begin{array}{l}\text { 50-90 years } \\
\text { non- } \\
\text { demented, } \\
\text { with } \\
\text { memory } \\
\text { complaints }\end{array}$ & 157 & $\begin{array}{l}\text { Phosphatidylserine } \\
\text { Containing } \quad \omega-3 \\
\text { Fatty Acids }\end{array}$ & 15 weeks & $\begin{array}{l}\text { The Rey } \\
\text { Auditory } \\
\text { Verbal Learn- } \\
\text { ing Test, Rey } \\
\text { Complex } \\
\text { Figure Test, } \\
\text { and a } \\
\text { computerized } \\
\text { cognitive } \\
\text { battery. }\end{array}$ & Improved & [118] \\
\hline \multirow[t]{2}{*}{4} & \multirow{2}{*}{$\begin{array}{l}\text { Sinn et al., } \\
2012\end{array}$} & \multirow{2}{*}{$\begin{array}{l}>65 \text { years } \\
\text { with MCI }\end{array}$} & \multirow[t]{2}{*}{50} & \multirow[t]{2}{*}{ EPA, DHA } & \multirow[t]{2}{*}{6 months } & Verbal fluency & Improved & \multirow[t]{2}{*}[120]{} \\
\hline & & & & & & $\begin{array}{l}\text { Rey Auditory } \\
\text { Verbal } \\
\text { Learning Test } \\
\text { and others }\end{array}$ & No change & \\
\hline 5 & $\begin{array}{l}\text { Külzow et } \\
\text { al., } 2016\end{array}$ & $50-75$ years & 44 & Omega 3 PUFA & 26 weeks & $\begin{array}{l}\text { object-location } \\
\text { memory }\end{array}$ & $\begin{array}{l}\text { Significantly } \\
\text { better }\end{array}$ & [121] \\
\hline 6 & $\begin{array}{l}\text { Stough et } \\
\text { al., } 2012\end{array}$ & $\begin{array}{l}\text { Healthy, } 45- \\
77 \text { years }\end{array}$ & 74 & DHA & 90 day & $\begin{array}{l}\text { Congnitive } \\
\text { function }\end{array}$ & $\begin{array}{l}\text { No } \\
\text { significant } \\
\text { effects }\end{array}$ & [122] \\
\hline 7 & $\begin{array}{l}\text { Andrieu et } \\
\text { al., } 2017\end{array}$ & $\begin{array}{l}\text { non- } \\
\text { demented, } \\
\text { aged } \quad 70 \\
\text { years or } \\
\text { older, with } \\
\text { memory } \\
\text { complaint }\end{array}$ & 1680 & EPA, DHA & 3 years & $\begin{array}{l}\text { Selective } \\
\text { Reminding test, } \\
\text { Mini-Mental } \\
\text { State } \\
\text { Examination } \\
\text { orientation } \\
\text { items, Digit } \\
\text { Symbol } \\
\text { Substitution } \\
\text { Test, and } \\
\text { Category } \\
\text { Naming Test }\end{array}$ & No effect & [123] \\
\hline 8 & $\begin{array}{l}\text { Kirby et } \\
\text { al., } 2010\end{array}$ & $\begin{array}{l}\text { Children } 8- \\
10 \text { years }\end{array}$ & 450 & EPA, DHA & 16 weeks & $\begin{array}{l}\text { Cognitive } \\
\text { assessments }\end{array}$ & $\begin{array}{l}\text { Significantly } \\
\text { higher for } \\
\text { many of the } \\
\text { parameteres }\end{array}$ & {$[125]$} \\
\hline
\end{tabular}

\section{Conclusions}

As a component of neuronal cell membrane, omega 3 fatty acids stabilize membrane fluidity, increasing the availability of receptors for neurotransmitter binding: by increasing syntaxin for SNARE complex formation, an increase in SNARE complex availability at the plasma membrane, expose a hidden site on Munc18a for SNARE complex binding, and/or bring a conformational change in Syntaxinla potentiates $\mathrm{Ca}^{2+}$ dependent exocytosis. Omega 3 PUFAs increase neurotransmitter concentration by inhibiting neurotransmitter uptake, increase 
availability of receptors for binding, act on several signaling molecules to enhance LTP and affect gene expression including neurotrophic factors. Thereby improving the memory of both demented and healthy animals. The accumulated knowledge indicates that healthy populations including school children and adults may have cognitive benefits from omega 3 PUFAs intake, and older adults with memory complaints or mild cognitive impairment, as well as subgroups of patients with Alzheimer's disease, may

\begin{abstract}
Abbreviations
AA: Arachidonic acid, BDNF: brain-derived neurotrophic factor, CaMKII: Ca2+/calmodulin-dependent protein kinase II, cAMP: cyclic adenosine monophosphate, CREB: cAMP response element binding protein, DA: dopamine, DHA: Docosahexaenoic acid, EPA: Eicosapentaenoic acid, LTD: long-term depression, LTP: long term potentiation, MAPK: mitogen-activated protein kinase, mGluRs: Metabotropic glutamate receptors, NMDA: N-methyl-D-aspartate, NPY: neuropeptide Y, PKA: protein kinase A, PUFA: Omega-3 polyunsaturated fatty acids, SNARE: Soluble NSF Attachment Protein Receptor, tPA: tissue plasminogen activator, Vglut: vesicular glutamate transporter
\end{abstract}

\title{
Declarations
}

The authors declare that they have no competing interests.

\section{Acknowledgements}

Not applicable

\section{Funding}

Not applicable

\section{Authors' contributions}

AA prepaired the primary draft, $\mathrm{MB}$ and WR revised the draft and amended by AA. All authors critically reviewed the manuscript. After all authors gave final approval of the paper to be published, AA; the corresponding author have the responsibility to submit the manuscript for publication.

\section{Consent for publication}

Not applicable

\section{References}

1. Calder PC, Yaqoob P. Understanding omega-3 polyunsaturated fatty acids. Postgrad Med. 2009;121(6):148-157.

2. James MJ, Ursin VM, Cleland LG. Metabolism of stearidonic acid in human subjects: comparison with the metabolism of other $n-3$ fatty acids. Am J Clin Nutr. 2003 May 1;77(5):1140-5.

3. Hastings N, Agaba M, Tocher DR, Leaver MJ, Dick JR, Sargent JR, et al. A vertebrate fatty acid desaturase with $\Delta 5$ and $\Delta 6$ activities. Proc Natl Acad Sci. 2001 Dec 4;98(25):14304-9.

4. Calder PC. Mechanisms of Action of (n-3) Fatty Acids. J Nutr. 2012 Mar 1;142(3):592S-599S.

5. Calder PC, Yaqoob P. Omega-3 polyunsaturated fatty acids and human health outcomes. BioFactors. 2009;35(3):266-72.

6. Su K-P, Huang S-Y, Chiu T-H, Huang K-C, Huang C-L, Chang H-C, et al. Omega-3 fatty acids for major depressive disorder during pregnancy: results from a randomized, double-blind, placebo-controlled trial. J Clin Psychiatry. 2008;69(4):644.

7. Burdge GC, Calder PC. Dietary $\alpha$-linolenic acid and health-related outcomes: a metabolic perspective. Nutr Res Rev. 2006;19(1):26-52.

8. Innis SM. Dietary omega 3 fatty acids and the developing brain. Brain Res. 2008 Oct 27;1237:35-43.

9. Arterburn LM, Hall EB, Oken H. Distribution, interconversion, and dose response of $\mathrm{n}-3$ fatty acids in humans. Am J Clin Nutr. 2006 Jun 1;83(6):1467S-1476S.

10. James MJ, Ursin VM, Cleland LG. Metabolism of stearidonic acid in human subjects: comparison with the metabolism of other n- 3 fatty acids. Am J Clin Nutr. 2003;77(5):1140-1145.

11. Miles EA, Banerjee T, Dooper MMBW, M'Rabet L, Graus YMF, Calder PC. The influence of different combinations of $\gamma$-linolenic acid, stearidonic acid and EPA on immune function in healthy young male subjects. Br J Nutr. 2004 Jun;91(6):893-903.

12. Givens DI, Gibbs RA. Current intakes of EPA and DHA in European populations and the potential of animal-derived foods to increase them: Symposium on 'How can the n-3 content of the diet be improved?' Proc Nutr Soc. 2008 Aug;67(3):273-80.

13. Bailey $\mathrm{CH}$, Bartsch D, Kandel ER. Toward a molecular definition of long-term memory storage. Proc 
Natl Acad Sci. 1996 Nov 26;93(24):13445-52.

14. Wenk G, Hughey D, Boundy V, Kim A, Walker L, Olton D. Neurotransmitters and memory: Role of cholinergic, serotonergic, and noradrenergic systems. Behav Neurosci. 1987;101(3):325-32.

15. Marinesco S, Carew TJ. Serotonin Release Evoked by Tail Nerve Stimulation in the CNS of Aplysia: Characterization and Relationship to Heterosynaptic Plasticity. J Neurosci. 2002 Mar 15;22(6):2299-312.

16. Buhot M-C, Martin S, Segu L. Role of serotonin in memory impairment. Ann Med. 2000 Jan 1;32(3):210-21.

17. Brunelli M, Castellucci V, Kandel ER. Synaptic facilitation and behavioral sensitization in Aplysia: possible role of serotonin and cyclic AMP. Science. 1976 Dec 10;194(4270):1178-81.

18. Kandel ER. The molecular biology of memory: cAMP, PKA, CRE, CREB-1, CREB-2, and CPEB. Mol Brain. 2012 May 14;5(1):14.

19. Kandel ER. The Molecular Biology of Memory Storage: A Dialogue Between Genes and Synapses. Science. 2001 Nov 2;294(5544):1030-8.

20. Klein M, Kandel ER. Mechanism of calcium current modulation underlying presynaptic facilitation and behavioral sensitization in Aplysia. Proc Natl Acad Sci. 1980 Nov 1;77(11):6912-6.

21. Augustine GJ. How does calcium trigger neurotransmitter release? Curr Opin Neurobiol. 2001 Jun $1 ; 11(3): 320-6$.

22. Giraudo CG, Eng WS, Melia TJ, Rothman JE. A Clamping Mechanism Involved in SNARE-Dependent Exocytosis. Science. 2006 Aug 4;313(5787):676-80.

23. Jahn R, Scheller RH. SNAREs - engines for membrane fusion. Nat Rev Mol Cell Biol. 2006 Sep;7(9):631-43.

24. McEntee WJ, Crook TH. Serotonin, memory, and the aging brain. Psychopharmacology (Berl). 1991 Feb 1;103(2):143-9.

25. Seyedabadi M, Fakhfouri G, Ramezani V, Mehr SE, Rahimian R. The role of serotonin in memory: interactions with neurotransmitters and downstream signaling. Exp Brain Res. 2014 Mar 1;232(3):72338 .

26. Antonov I, Kandel ER, Hawkins RD. Presynaptic and Postsynaptic Mechanisms of Synaptic Plasticity and Metaplasticity during Intermediate-Term Memory Formation in Aplysia. J Neurosci. 2010 Apr 21;30(16):5781-91.

27. Rosenzweig MR, Bennett EL, Colombo PJ, Lee DW, Serrano PA. Short-term, intermediate-term, and long-term memories. Behav Brain Res. 1993 Nov 30;57(2):193-8.

28. Bekinschtein P, Cammarota M, Igaz LM, Bevilaqua LRM, Izquierdo I, Medina JH. Persistence of LongTerm Memory Storage Requires a Late Protein Synthesis- and BDNF- Dependent Phase in the Hippocampus. Neuron. 2007 Jan 18;53(2):261-77.

29. Guan Z, Giustetto M, Lomvardas S, Kim J-H, Miniaci MC, Schwartz JH, et al. Integration of LongTerm-Memory-Related Synaptic Plasticity Involves Bidirectional Regulation of Gene Expression and Chromatin Structure. Cell. 2002 Nov 15;111(4):483-93.

30. Bliss TVP, Collingridge GL. A synaptic model of memory: long-term potentiation in the hippocampus. Nature. 1993 Jan;361(6407):31.

31. Abel T, Nguyen PV, Barad M, Deuel TAS, Kandel ER, Bourtchouladze R. Genetic Demonstration of a Role for PKA in the Late Phase of LTP and in Hippocampus-Based Long-Term Memory. Cell. 1997 Mar 7;88(5):615-26.

32. Lynch MA. Long-Term Potentiation and Memory. Physiol Rev. 2004 Jan 1;84(1):87-136.

33. Abel T, Lattal KM. Molecular mechanisms of memory acquisition, consolidation and retrieval. Curr Opin Neurobiol. 2001 Apr 1;11(2):180-7.

34. Kandel ER, Dudai Y, Mayford MR. The Molecular and Systems Biology of Memory. Cell. 2014 Mar 27;157(1):163-86.

35. Collingridge GL, Bliss TVP. Memories of NMDA receptors and LTP. Trends Neurosci. 1995 Feb $1 ; 18(2): 54-6$.

36. Purcell AL, Sharma SK, Bagnall MW, Sutton MA, Carew TJ. Activation of a Tyrosine Kinase-MAPK Cascade Enhances the Induction of Long-Term Synaptic Facilitation and Long-Term Memory in Aplysia. Neuron. 2003 Feb 6;37(3):473-84.

37. Kelleher RJ, Govindarajan A, Jung H-Y, Kang H, Tonegawa S. Translational Control by MAPK Signaling in Long-Term Synaptic Plasticity and Memory. Cell. 2004 Feb 6;116(3):467-79.

38. Kandel ER, Dudai Y, Mayford MR. The Molecular and Systems Biology of Memory. Cell. 2014 Mar 27;157(1):163-86.

39. Hawkins RD, Kandel ER, Bailey CH. Molecular Mechanisms of Memory Storage in Aplysia. Biol Bull. 2006 Jun 1;210(3):174-91.

40. Weng G, Bhalla US, Iyengar R. Complexity in Biological Signaling Systems. Science. 1999 Apr 


\section{2;284(5411):92-6.}

41. Du L, Richter JD. Activity-dependent polyadenylation in neurons. RNA. 2005 Sep 1;11(9):1340-7.

42. Kandel ER, Dudai Y, Mayford MR. The Molecular and Systems Biology of Memory. Cell. 2014 Mar 27;157(1):163-86.

43. Yin JC, Tully T. CREB and the formation of long-term memory. Curr Opin Neurobiol. 1996 Apr $1 ; 6(2): 264-8$.

44. Matsuoka Y. Clearance of fear memory from the hippocampus through neurogenesis by omega-3 fatty acids: a novel preventive strategy for posttraumatic stress disorder? Biopsychosoc Med. 2011 Feb 8;5:3.

45. Ammann EM, Pottala JV, Robinson JG, Espeland MA, Harris WS. Erythrocyte omega-3 fatty acids are inversely associated with incident dementia: Secondary analyses of longitudinal data from the Women's Health Initiative Memory Study (WHIMS). Prostaglandins Leukot Essent Fatty Acids. 2017 Jun;121:6875.

46. Lei X, Zhang W, Liu T, Xiao H, Liang W, Xia W, et al. Perinatal Supplementation with Omega-3 Polyunsaturated Fatty Acids Improves Sevoflurane-Induced Neurodegeneration and Memory Impairment in Neonatal Rats. PLoS ONE [Internet]. 2013 Aug 13 [cited 2019 Feb 2];8(8). Available from: https://www.ncbi.nlm.nih.gov/pmc/articles/PMC3742769/

47. Richter Y, Herzog Y, Cohen T, Steinhart Y. The effect of phosphatidylserine-containing omega-3 fatty acids on memory abilities in subjects with subjective memory complaints: a pilot study. Clin Interv Aging. 2010;5:313-6.

48. Kelly RB. Storage and release of neurotransmitters. Cell. 1993 Jan 1;72:43-53.

49. Südhof TC. The Presynaptic Active Zone. Neuron. 2012 Jul 12;75(1):11-25.

50. Sudhof TC. The synaptic vesicle cycle. Annu Rev Neurosci. 2004;27:509.

51. Gil C, Soler-Jover A, Blasi J, Aguilera J. Synaptic proteins and SNARE complexes are localized in lipid rafts from rat brain synaptosomes. Biochem Biophys Res Commun. 2005 Apr 1;329(1):117-24.

52. Linetti A, Fratangeli A, Taverna E, Valnegri P, Francolini M, Cappello V, et al. Cholesterol reduction impairs exocytosis of synaptic vesicles. J Cell Sci. 2010 Jan 1;jcs.060681.

53. Lv J-H, He L, Sui S-F. Lipid rafts association of synaptotagmin I on synaptic vesicles. Biochem Mosc. 2008 Mar 1;73(3):283-8.

54. Taverna E, Saba E, Linetti A, Longhi R, Jeromin A, Righi M, et al. Localization of synaptic proteins involved in neurosecretion in different membrane microdomains. J Neurochem. 2007;100(3):664-677.

55. Hajjar T, Goh YM, Rajion MA, Vidyadaran S, Li TA, Ebrahimi M. Alterations in neuronal morphology and synaptophysin expression in the rat brain as a result of changes in dietary n-6: n-3 fatty acid ratios. Lipids Health Dis. 2013 Jul 26;12:113.

56. Géraldine M, Stéphanie D, Bénédicte L, Isabelle D, Monique L, Sylvie V. DHA enhances the noradrenaline release by SH-SY5Y cells. Neurochem Int. 2010 Jan 1;56(1):94-100.

57. Park SB, Coull JT, McShane RH, Young AH, Sahakian BJ, Robbins TW, et al. Tryptophan depletion in normal volunteers produces selective impairments in learning and memory. Neuropharmacology. 1994 Mar 1;33(3):575-88.

58. McNamara RK, Able J, Liu Y, Jandacek R, Rider T, Tso P, et al. Omega-3 fatty acid deficiency during perinatal development increases serotonin turnover in the prefrontal cortex and decreases midbrain tryptophan hydroxylase-2 expression in adult female rats: Dissociation from estrogenic effects. J Psychiatr Res. 2009 Mar 1;43(6):656-63.

59. Rees D, Miles EA, Banerjee T, Wells SJ, Roynette CE, Wahle KW, et al. Dose-related effects of eicosapentaenoic acid on innate immune function in healthy humans: a comparison of young and older men. Am J Clin Nutr. 2006 Feb 1;83(2):331-42.

60. Barton RG, Wells CL, Carlson A, Singh R, Sullivan JJ, Cerra FB. Dietary omega-3 fatty acids decrease mortality and Kupffer cell prostaglandin E2 production in a rat model of chronic sepsis. J Trauma. 1991 Jun;31(6):768-73; discussion 773-4.

61. Hibbeln JR, Linnoila M, Umhau JC, Rawlings R, George DT, Salem N. Essential fatty acids predict metabolites of serotonin and dopamine in cerebrospinal fluid among healthy control subjects, and earlyand late-onset alcoholics. Biol Psychiatry. 1998 Aug 15;44(4):235-42.

62. Escribá PV, Wedegaertner PB, Goñi FM, Vögler O. Lipid-protein interactions in GPCR-associated signaling. Biochim Biophys Acta BBA-Biomembr. 2007;1768(4):836-852.

63. Wassall SR, Stillwell W. Polyunsaturated fatty acid-cholesterol interactions: domain formation in membranes. Biochim Biophys Acta BBA-Biomembr. 2009;1788(1):24-32.

64. Heron DS, Shinitzky M, Hershkowitz M, Samuel D. Lipid fluidity markedly modulates the binding of serotonin to mouse brain membranes. Proc Natl Acad Sci. 1980 Dec 1;77(12):7463-7.

65. Chalon S. Omega-3 fatty acids and monoamine neurotransmission. Prostaglandins Leukot Essent Fatty Acids. 2006 Oct 1;75(4):259-69. 
66. Owens S de la P, Innis SM. Docosahexaenoic and Arachidonic Acid Prevent a Decrease in Dopaminergic and Serotoninergic Neurotransmitters in Frontal Cortex Caused by a Linoleic and $\alpha$ Linolenic Acid Deficient Diet in Formula-fed Piglets. J Nutr. 1999 Nov 1;129(11):2088-93.

67. Zemdegs J, Rainer Q, Grossmann CP, Rousseau-Ralliard D, Grynberg A, Ribeiro E, et al. Anxiolyticand Antidepressant-Like Effects of Fish Oil-Enriched Diet in Brain-Derived Neurotrophic Factor Deficient Mice. Front Neurosci [Internet]. 2018 Dec 21 [cited 2019 Feb 1];12. Available from: https:/www.ncbi.nlm.nih.gov/pmc/articles/PMC6308198/

68. Avraham Y, Saidian M, Burston JJ, Mevorach R, Vorobiev L, Magen I, et al. Fish oil promotes survival and protects against cognitive decline in severely undernourished mice by normalizing satiety signals. $\mathrm{J}$ Nutr Biochem. 2011 Aug;22(8):766-76.

69. Riedel G, Platt B, Micheau J. Glutamate receptor function in learning and memory. Behav Brain Res. 2003 Mar 18;140(1):1-47.

70. Latour A, Grintal B, Champeil-Potokar G, Hennebelle M, Lavialle M, Dutar P, et al. Omega-3 fatty acids deficiency aggravates glutamatergic synapse and astroglial aging in the rat hippocampal CA1. Aging Cell. 2013;12(1):76-84.

71. Grintal B, Champeil-Potokar G, Lavialle M, Vancassel S, Breton S, Denis I. Inhibition of astroglial glutamate transport by polyunsaturated fatty acids: Evidence for a signalling role of docosahexaenoic acid. Neurochem Int. 2009 Jul 1;54(8):535-43.

72. Calon F, Lim GP, Morihara T, Yang F, Ubeda O, Salem Jr N, et al. Dietary n-3 polyunsaturated fatty acid depletion activates caspases and decreases NMDA receptors in the brain of a transgenic mouse model of Alzheimer's disease. Eur J Neurosci. 2005 Aug 1;22(3):617-26.

73. Dyall SC, Michael GJ, Whelpton R, Scott AG, Michael-Titus AT. Dietary enrichment with omega-3 polyunsaturated fatty acids reverses age-related decreases in the GluR2 and NR2B glutamate receptor subunits in rat forebrain. Neurobiol Aging. 2007 Mar 1;28(3):424-39.

74. Moreira JD, Knorr L, Ganzella M, Thomazi AP, de Souza CG, de Souza DG, et al. Omega-3 fatty acids deprivation affects ontogeny of glutamatergic synapses in rats: Relevance for behavior alterations. Neurochem Int. 2010 May 1;56(6):753-9.

75. Hasselmo ME. Neuromodulation: acetylcholine and memory consolidation. Trends Cogn Sci. 1999 Sep 1;3(9):351-9.

76. Hasselmo ME. The role of acetylcholine in learning and memory. Curr Opin Neurobiol. 2006 Dec $1 ; 16(6): 710-5$.

77. Taepavarapruk P, Song C. Reductions of acetylcholine release and nerve growth factor expression are correlated with memory impairment induced by interleukin- $1 \beta$ administrations: effects of omega- 3 fatty acid EPA treatment. J Neurochem. 2010;112(4):1054-64.

78. Aïd S, Vancassel S, Poumès-Ballihaut $\mathrm{C}$, Chalon S, Guesnet $\mathrm{P}$, Lavialle M. Effect of a diet-induced n-3 PUFA depletion on cholinergic parameters in the rat hippocampus. J Lipid Res. 2003 Aug 1;44(8):154551.

79. Chalon S. Omega-3 fatty acids and monoamine neurotransmission. Prostaglandins Leukot Essent Fatty Acids. 2006 Oct 1;75(4):259-69.

80. Guixà-González R, Javanainen M, Gómez-Soler M, Cordobilla B, Domingo JC, Sanz F, et al. Membrane omega-3 fatty acids modulate the oligomerisation kinetics of adenosine $A_{2 A}$ and dopamine $D_{2}$ receptors. Sci Rep. 2016 Jan 22;6:19839.

81. Zimmer L, Delpal S, Guilloteau D, Aïoun J, Durand G, Chalon S. Chronic n-3 polyunsaturated fatty acid deficiency alters dopamine vesicle density in the rat frontal cortex. Neurosci Lett. 2000 Apr $21 ; 284(1): 25-8$.

82. Chen C, Tonegawa S. Molecular Genetic Analysis of Synaptic Plasticity, Activity-Dependent Neural Development, Learning, and Memory in the Mammalian Brain. Annu Rev Neurosci. 1997;20(1):157-84.

83. Malenka RC, Bear MF. LTP and LTD: An Embarrassment of Riches. Neuron. 2004 Sep 30;44(1):5-21.

84. Barria A, Muller D, Derkach V, Griffith LC, Soderling TR. Regulatory Phosphorylation of AMPA-Type Glutamate Receptors by CaM-KII During Long-Term Potentiation. Science. 1997 Jun 27;276(5321):2042-5.

85. Lee H-K, Barbarosie M, Kameyama K, Bear MF, Huganir RL. Regulation of distinct AMPA receptor phosphorylation sites during bidirectional synaptic plasticity. Nature. 2000 Jun;405(6789):955-9.

86. Lee H-K, Kameyama K, Huganir RL, Bear MF. NMDA Induces Long-Term Synaptic Depression and Dephosphorylation of the GluR1 Subunit of AMPA Receptors in Hippocampus. Neuron. 1998 Nov 1;21(5):1151-62.

87. Yuste R, Bonhoeffer T. Morphological Changes in Dendritic Spines Associated with Long-Term Synaptic Plasticity. Annu Rev Neurosci. 2001;24(1):1071-89.

88. Abraham WC, Williams JM. Properties and mechanisms of LTP maintenance. The Neuroscientist. 
2003;9(6):463-474.

89. Malinow R, Malenka RC. AMPA Receptor Trafficking and Synaptic Plasticity. Annu Rev Neurosci. 2002;25(1):103-26.

90. Lynch MA, Voss KL. Membrane Arachidonic Acid Concentration Correlates with Age and Induction of Long-term Potentiation in the Dentate Gyrus in the Rat. Eur J Neurosci. 1994 Jun 1;6(6):1008-14.

91. McGahon B, Clements MP, Lynch MA. The ability of aged rats to sustain long-term potentiation is restored when the age-related decrease in membrane arachidonic acid concentration is reversed. Neuroscience. 1997 Aug 26;81(1):9-16.

92. McGahon BM, Martin DSD, Horrobin DF, Lynch MA. Age-related changes in synaptic function: analysis of the effect of dietary supplementation with $\omega-3$ fatty acids. Neuroscience. 1999 Sep 1;94(1):305-14.

93. Fujita S, Ikegaya Y, Nishikawa M, Nishiyama N, Matsuki N. Docosahexaenoic acid improves long-term potentiation attenuated by phospholipase A2 inhibitor in rat hippocampal slices. Br J Pharmacol. 2001;132(7):1417-22.

94. Young C, Gean P-W, Wu S-P, Lin C-H, Shen Y-Z. Cancellation of low-frequency stimulation-induced long-term depression by docosahexaenoic acid in the rat hippocampus. Neurosci Lett. 1998 May 15;247(2):198-200.

95. Yamamoto N, Saitoh M, Moriuchi A, Nomura M, Okuyama H. Effect of dietary alphalinolenate/linoleate balance on brain lipid compositions and learning ability of rats. J Lipid Res. 1987 Feb 1;28(2):144-51.

96. FUJIMOTO K. The effect of dietary docosahexaenoate on the learning ability of rats. Health Eff Fish Fish Oils. 1989;275-84.

97. Zucker RS, Regehr WG. Short-Term Synaptic Plasticity. Annu Rev Physiol. 2002;64(1):355-405.

98. Honoré E, Barhanin J, Attali B, Lesage F, Lazdunski M. External blockade of the major cardiac delayedrectifier $\mathrm{K}+$ channel $(\mathrm{Kv} 1.5)$ by polyunsaturated fatty acids. Proc Natl Acad Sci. 1994 Mar 1;91(5):1937-41.

99. Aniksztejn L, Ben-Ari Y. Novel form of long-term potentiation produced by a K+channel blocker in the hippocampus. Nature. 1991 Jan;349(6304):67-9.

100. Keros S, McBain CJ. Arachidonic Acid Inhibits Transient Potassium Currents and Broadens Action Potentials during Electrographic Seizures in Hippocampal Pyramidal and Inhibitory Interneurons. J Neurosci. 1997 May 15;17(10):3476-87.

101. Colbert CM, Pan E. Arachidonic Acid Reciprocally Alters the Availability of Transient and Sustained Dendritic K+ Channels in Hippocampal CA1 Pyramidal Neurons. J Neurosci. 1999 Oct 1;19(19):816371.

102. Villarroel A, Schwarz TL. Inhibition of the Kv4 (Shal) family of transient K+ currents by arachidonic acid. J Neurosci. 1996 Feb 1;16(3):1016-25.

103. Hoffman DA, Magee JC, Colbert CM, Johnston D. K+ channel regulation of signal propagation in dendrites of hippocampal pyramidal neurons. Nature. 1997;387(6636):869.

104. Linden DJ. The Return of the Spike: Postsynaptic Action Potentials and the Induction of LTP and LTD. Neuron. 1999 Apr 1;22(4):661-6.

105. Gasparini S. Distance- and activity-dependent modulation of spike back-propagation in layer $\mathrm{V}$ pyramidal neurons of the medial entorhinal cortex. J Neurophysiol. 2011 Mar;105(3):1372-9.

106. Hoffman DA, Johnston D. Neuromodulation of Dendritic Action Potentials. J Neurophysiol. 1999 Jan 1;81(1):408-11.

107. Wu A, Ying Z, Gomez-Pinilla F. Docosahexaenoic acid dietary supplementation enhances the effects of exercise on synaptic plasticity and cognition. Neuroscience. 2008 Aug 26;155(3):751-9.

108. Wu A, Ying Z, Gomez-Pinilla F. DHA dietary supplementation enhances the effects of exercise on synaptic plasticity and cognition. Neuroscience. 2008 Aug 26;155(3):751.

109. Tyagi E, Agrawal R, Zhuang Y, Abad C, Waschek JA, Gomez-Pinilla F. Vulnerability Imposed by Diet and Brain Trauma for Anxiety-Like Phenotype: Implications for Post-Traumatic Stress Disorders. PLoS ONE [Internet]. 2013 Mar 6 [cited 2019 Feb 1];8(3). Available from: https:/www.ncbi.nlm.nih.gov/pmc/articles/PMC3590222/

110. Kumar PR, Essa MM, Al-Adawi S, Dradekh G, Memon MA, Akbar M, et al. Omega-3 Fatty Acids Could Alleviate the Risks of Traumatic Brain Injury - A Mini Review. J Tradit Complement Med. 2014;4(2):89-92.

111. Kitajka K, Puskás LG, Zvara Á, Hackler L, Barceló-Coblijn G, Yeo YK, et al. The role of n-3 polyunsaturated fatty acids in brain: Modulation of rat brain gene expression by dietary n-3 fatty acids. Proc Natl Acad Sci. 2002 Mar 5;99(5):2619-24.

112. Bourre J-M, Francois M, Youyou A, Dumont O, Piciotti M, Pascal G, et al. The Effects of Dietary $\alpha-$ 
Linolenic Acid on the Composition of Nerve Membranes, Enzymatic Activity, Amplitude of Electrophysiological Parameters, Resistance to Poisons and Performance of Learning Tasks in Rats. J Nutr. 1989 Dec 1;119(12):1880-92.

113. Gnegy ME. Ca2+/Calmodulin Signaling in NMDA-lnduced Synaptic Plasticity. Crit Rev Neurobiol [Internet]. $2000 \quad$ [cited $2019 \quad$ Feb 4$] ; 14(2)$ Available from: http://www.dl.begellhouse.com/journals/7b004699754c9fe6,0bac4fef6e7e8b0a,7937e40a41ae1b04.html

114. George JM, Jin H, Woods WS, Clayton DF. Characterization of a novel protein regulated during the critical period for song learning in the zebra finch. Neuron. 1995;15(2):361-372.

115. Black JE, Isaacs KR, Anderson BJ, Alcantara AA, Greenough WT. Learning causes synaptogenesis, whereas motor activity causes angiogenesis, in cerebellar cortex of adult rats. Proc Natl Acad Sci. 1990 Jul 1;87(14):5568-72.

116. Jaremka LM, Derry HM, Bornstein R, Prakash RS, Peng J, Belury MA, et al. Omega-3 Supplementation and Loneliness-Related Memory Problems: Secondary Analyses Of A Randomized Controlled Trial. Psychosom Med. 2014 Oct;76(8):650-8.

117. Konagai C, Yanagimoto K, Hayamizu K, Han L, Tsuji T, Koga Y. Effects of krill oil containing n-3 polyunsaturated fatty acids in phospholipid form on human brain function: a randomized controlled trial in healthy elderly volunteers. Clin Interv Aging. 2013;8:1247-57.

118. Vakhapova V, Cohen T, Richter Y, Herzog Y, Korczyn AD. Phosphatidylserine Containing $\omega-3$ Fatty Acids May Improve Memory Abilities in Non-Demented Elderly with Memory Complaints: A DoubleBlind Placebo-Controlled Trial. Dement Geriatr Cogn Disord. 2010;29(5):467-74.

119. Hooper C, de Souto Barreto P, Coley N, Cantet C, Cesari M, Andrieu S, et al. Cognitive changes with omega-3 polyunsaturated fatty acids in non-demented older adults with low omega-3 index. J Nutr Health Aging. 2017 Nov 1;21(9):988-93.

120. Sinn N, Milte CM, Street SJ, Buckley JD, Coates AM, Petkov J, et al. Effects of n-3 fatty acids, EPA v. DHA, on depressive symptoms, quality of life, memory and executive function in older adults with mild cognitive impairment: a 6-month randomised controlled trial. Br J Nutr. 2012 Jun;107(11):1682-93.

121. Külzow N, Witte AV, Kerti L, Grittner U, Schuchardt JP, Hahn A, et al. Impact of Omega-3 Fatty Acid Supplementation on Memory Functions in Healthy Older Adults. J Alzheimers Dis. 2016 Jan 1;51(3):713-25.

122. Stough C, Downey L, Silber B, Lloyd J, Kure C, Wesnes K, et al. The effects of 90-day supplementation with the Omega-3 essential fatty acid docosahexaenoic acid (DHA) on cognitive function and visual acuity in a healthy aging population. Neurobiol Aging. 2012 Apr 1;33(4):824.e1-824.e3.

123. Andrieu S, Guyonnet S, Coley N, Cantet C, Bonnefoy M, Bordes S, et al. Effect of long-term omega 3 polyunsaturated fatty acid supplementation with or without multidomain intervention on cognitive function in elderly adults with memory complaints (MAPT): a randomised, placebo-controlled trial. Lancet Neurol. 2017 May 1;16(5):377-89.

124. Kirby A, Woodward A, Jackson S, Wang Y, Crawford MA. Childrens' learning and behaviour and the association with cheek cell polyunsaturated fatty acid levels. Res Dev Disabil. 2010 May 1;31(3):731-42.

125. Kirby A, Woodward A, Jackson S, Wang Y, Crawford MA. A double-blind, placebo-controlled study investigating the effects of omega-3 supplementation in children aged 8-10 years from a mainstream school population. Res Dev Disabil. 2010 May 1;31(3):718-30.

126. Bauer I, Hughes M, Rowsell R, Cockerell R, Pipingas A, Crewther S, et al. Omega-3 supplementation improves cognition and modifies brain activation in young adults. Hum Psychopharmacol Clin Exp. 2014 Mar 1;29(2):133-44.

127. Cederholm T. Fish consumption and omega-3 fatty acid supplementation for prevention or treatment of cognitive decline, dementia or Alzheimer's disease in older adults - any news? Curr Opin Clin Nutr Metab Care. 2017 Mar;20(2):104.

128. Vakhapova V, Richter Y, Cohen T, Herzog Y, Korczyn AD. Safety of phosphatidylserine containing omega-3 fatty acids in non-demented elderly: a double-blind placebo-controlled trial followed by an open-label extension. BMC Neurol. 2011 Jun 28;11(1):79. 